\title{
Influence of using a blend of rennet casein and whey protein concentrate as protein source on the quality of Mozzarella cheese analogue
}

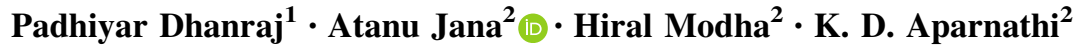

Revised: 24 January 2017/Accepted: 31 January 2017/Published online: 13 February 2017

(C) Association of Food Scientists \& Technologists (India) 2017

\begin{abstract}
The effect of incorporating whey protein concentrate (WPC) on the quality characteristics of Mozzarella cheese analogue (MCA) based on rennet casein (RC) was studied. The proportion of RC:WPC tried out were 95:5, 90:10, and 85:15 w/w. The formulation of MCA comprised of $23.5 \%$ of blend of RC and WPC, $15 \%$ specialty vegetable fat, $2.75 \%$ trisodium citrate + disodium hydrogen orthophosphate $(2.5: 1, \mathrm{w} / \mathrm{w}), 0.07 \%$ calcium chloride, $0.6 \%$ citric acid, $1.1 \% \mathrm{NaCl}, 1.5 \%$ cheese bud flavoring, and rest water. Varying the proportion of RC and WPC had a significant influence on the composition, textural properties, baking qualities and sensory quality of MCA judged as a topping on pizza pie. MCA made using protein blends (RC:WPC - 90:10 or 85:15) behaved satisfactorily during pizza baking trials. However, looking at the superiority of MCA made using RC:WPC (90:10) with regard to shred quality and marginal superiority in terms of the total sensory score of cheese, judged as pizza topping, the former blend (i.e. RC:WPC, 90:10) was selected. The MCA obtained employing such protein blend had composition similar to that of Pizza cheese prepared from cheese milk and had requisite baking characteristics needed as a pizza topping. It is recommended to use a blend of RC and WPC $(90: 10)$ as the protein source in the formulation of MCA to obtain nutritionally superior cheese product having desired functional properties for its end use in baking applications.
\end{abstract}

Atanu Jana

atanujn@gmail.com

1 Baroda Dairy, Vadodara, Gujarat, India

2 Department of Dairy Technology, SMC College of Dairy Science, Anand Agricultural University, Anand, Gujarat 388 110, India
Keywords Mozzarella cheese analogue $\cdot$ Rennet casein Whey protein concentrate $\cdot$ Composition $\cdot$ Texture $\cdot$ Baking quality

\section{Introduction}

Cheese analogues synonymously known as cheese substitute or imitations, are the products that substitute or imitate cheese in part or whole. In such products milk fat, milk protein or both may be partly or fully replaced by non-milk components, usually of vegetable origin (Forsum 1973). Analogue cheese products are made utilizing processed cheese manufacturing technique with the help of heat, mechanical shear and emulsifying salts. Analogue cheese products can be classified as (a) Dairy, (b) Partial dairy, or (c) Non-dairy analogues (Chavan and Jana 2007). Cheese analogues are easy to prepare, requires less time for manufacture (i.e. about $2 \mathrm{~h}$ for analogue vs. $5-7 \mathrm{~h}$ for natural Mozzarella cheese) and can be 'tailor-made' as per the specifications of the pizza retailer. Mozzarella cheese analogue (MCA) has been reported to be functionally more stable during refrigerated storage than natural mozzarella cheese (NMC) since the raw material (protein powder - casein/caseinates) used in MCA manufacture has uniform composition; fresh milk is known to vary in its composition. Such stability makes analogues very attractive to the food processing and service industries (Chavan and Jana 2007).

Cheese analogues are produced commercially in several countries, however, the information relating to their formulation and method of manufacture are mostly patented. Analogue cheese was introduced in the US in early 1970s. Cheese alternatives are being produced and sold in USA, UK, Sweden, France, Germany, Belgium, Switzerland and 
Australia. The annual production of analogue cheese in the USA amounts to about 3,00,000 tonnes; the major products being substitutes for, or imitation of low-moisture Mozzarella, Cheddar and pasteurized processed cheese (Fox et al. 2017).

The cheese variety which has been imitated the most is Mozzarella cheese, due to the growing popularity of pizza world over. Cheese is the key ingredient in such applications. The major application of cheese analogue is in compounded or formulated foods manufactured by catering or industrial establishments (Chavan and Jana 2007). The manufacture of cheese analogue allows manufacturers greater scope in manipulating constituents toward nutritional, textural and economic ends.

The world cheese production reached 20.0 million MT in 2011 (www.pmfood.dk/upl/WCMINFORMATION.pdf). Mozzarella (main ingredient of pizza) is Americás favorite cheese and accounts for nearly one-third of the consumption. Analogue cheese is available in retail sector and accounted for 18,000 tonnes for supermarket sales in United States in 2005 (i.e. $7.0 \%$ of processed cheese sales) (Dairy facts 2006). In the year 2000, the demand for Pizza cheese grew at $8.0 \%$ per year in Europe. Analogue cheese is sold into the industrial sector, and the most common variety sold has functional properties designed to mimic those of natural Mozzarella cheese.

Casein or caseinates is the preferred protein source in the preparation of MCA (Chavan and Jana 2007). Rennet casein is preferred over alternative protein sources (i.e. acid casein, caseinates) in the manufacture of MCA due to its desirable flavor and functional properties. Besides fat, protein is the major constituent affecting the quality of the cheese analogue. MCA has been prepared using casein or/caseinates at levels ranging from 23.0 to $28.5 \%$ (O'Malley et al. 2000; Mounsey and O'Riordan 2008).

Besides casein, whey proteins are a good source of protein. Whey proteins are highly nutritious food ingredients. Ultrafiltered Whey Protein Concentrates (WPC) is reported to possess higher protein efficiency ratio (PER) value while gel-filtered WPC has higher net protein utilization (NPU) value compared to those of casein (Forsum 1973). Branched chain amino acids (BCAAs) refer to a group of essential amino acids, including leucine, isoleucine, and valine. Nearly $25 \%$ of all whey protein is made up of BCAAs (Almeida et al. 2016). Researchers believe that BCAAs, specifically leucine are responsible for regulating the protein synthesis which are important for tissue growth and repair. Whey proteins are also rich in sulphur containing amino acids like cysteine and methionine which enhance immune function through intracellular conversion to glutathione (Anon. 2008).

Whey proteins have important functional properties in cheese systems such as the ability to act as emulsifiers (i.e. water and fat binding properties), attain gelation and impart foaming properties which makes them very versatile food ingredients (Jayaprakasha and Brueckner 1999; Dees 2002). Application of WPCs in the manufacture of cheese analogues can contribute to the essential savings of basic material (especially using low protein concentrates) and even helped in improving the rheological properties of the resultant product (Solowiej 2007).

In normal cheese making from milk, the valuable whey proteins are lost during separation of whey. In case of cheese analogues, incorporation of any value-added ingredient is possible; whey proteins are one such valued ingredient.

Replacement of Kasseri cheese with WPC (24.0\% protein) used at levels of $9.0-39.0 \%(\mathrm{w} / \mathrm{w})$ caused a decrease in the hardness of cheese analogues (Kaminarides and Stachtiaris 2000). The hardness of cheese/cheese analogue system depends on the type of protein used in the formulation, protein content of cheese, $\mathrm{pH}$ of system, moisture content, etc. Casein is the predominant protein in rennet based cheese system wherein calcium associated with casein also confers rigidity (firmness) to the cheese matrix. Application of WPC in cheese system has been found to interfere with the casein crosslinks; it also decreased the protein content of cheese (since WPC had $24 \%$ protein) leading to decrease in the hardness of the cheese analogues.

Whey proteins have been utilized as a partial substitute $(\leq 3.75 \mathrm{~g} / 100 \mathrm{~g})$ for casein in the manufacture of MCA (Murphy 1999; Solowiej 2007). Replacement of RC with WPC (up to $3 \mathrm{~g} / 100 \mathrm{~g}$ of RC) did not significantly affect the texture of cheese analogues; however, increasing casein replacement level to $15 \mathrm{~g} / 100 \mathrm{~g}$ significantly decreased the meltability of cheese analogue (Murphy 1999).An increase in the amount of WPC in cheese analogue formulation from 1.25 to $11.25 \mathrm{~g} / 100 \mathrm{~g}$ led to decrease in the hardness and meltability of cheese analogues. The decrease in the hardness of cheese analogue when using greater level of WPC in the formulation is already discussed earlier. The meltability of cheese analogue is based on the type of protein ingredient used in the formulation (i.e. casein/caseinates, whey proteins). WPC is known to possess emulsifying properties. An over-emulsified cheese tends to be non-melting, while the reverse is true for an under-emulsified cheese. WPC containing cheese system tends to be better emulsified, retarding its meltability (Shimp 1985). A crumbly mouth feel was felt in cheese analogue containing mixture of RC and WPC, as against fully RC-based cheese (Murphy 1999). Addition of WPC-35 and WPC-65 at 3.0\% level caused the hardness of processed cheese analogues to increase compared to those made using acid casein alone (Solowiej 2007; Solowiej et al. 2010).

A key aspect of cooking performance of Mozzarella cheese is its heat-induced functionality, including melting 
or flowability (O'Riordan et al. 2011). Incorporation of WPC to casein based cheese analogue is bound to affect the sensory quality, protein content as well as the baking properties of resultant product. Hence, the study was planned to observe the influence of incorporating WPC on the quality of MCA based on rennet casein.

\section{Materials and methods}

Rennet casein ( $80.85 \%$ protein) and Whey Protein Concentrate (WPC-PROCON-3700 having $68.32 \%$ protein) were procured from M/s. Mahaan Protein Ltd., Kosikalan, UP. Specialty palm kernel oil (partly hydrogenated fat) based vegetable fat (Code No. DFR) was procured from M/s. Kamani Oil Industries Pvt. Ltd., Mumbai. The refined, bleached and deodorized palm kernel oil had an average meting point of $32{ }^{\circ} \mathrm{C}$. Anhydrous citric acid was obtained from M/s. Loba Chemie Pvt. Ltd., Mumbai. Calcium chloride, dihydrate was obtained from M/s. Merck Ltd., Mumbai. Tri-sodium citrate, dihydrate and di-sodium hydrogen orthophosphate, dihydrate were obtained from M/s. Qualigens Fine Chemicals, Mumbai. 'Tata' brand vacuum-evaporated salt manufactured by $\mathrm{M} / \mathrm{s}$. Tata Chemicals Ltd., Mumbai was obtained from local market. Natural cheese flavouring (Mozzarella cheese bud-No. 34/1026) powder was obtained from M/s. Duke Thomson's International through their representative at Indore, MP.

\section{Preparation of Mozzarella cheese analogue}

Mozzarella cheese analogue (MCA) was made as per the process standardized by Shah et al. (2010) substituting plastic cream with palm kernel vegetable fat. Rennet casein (@23.5\%), cheese bud flavouring @ 1.5\%), calcium chloride (@0.07\%) and common salt (@1.1\%) was added to hot $\left(80{ }^{\circ} \mathrm{C}\right)$ potable water $(55.73 \%)$ containing mixture of trisodium citrate and disodium hydrogen phosphate (3:1 w/w@ 2.5\%) as emulsifying salt. After part acidification with lactic acid solution (1:10 w/v of water), vegetable fat (@ 15.0\%) in melted condition was added to the casein based dough and subsequently again acidified to desired $\mathrm{pH}$ using the previously prepared lactic acid solution (totally $0.55 \%$ lactic acid in the formulation). The final dough formed was heated to $80{ }^{\circ} \mathrm{C}$ for about $3 \mathrm{~min}$, shaped into a ball form and then allowed to cool first to room temperature and then to refrigerated temperature. A Hobart food processor (M/s. Hobart Corp. Canada-Model No. N 50) operating at three different speeds was used to blend the ingredients to form a dough. A separate stainless steel vessel was used to heat the dough-like mass. During the experimentation, $500 \mathrm{~g}$ of cheese analogue was prepared for each treatment under study. The experiment was replicated five times.

\section{Chemical analyses}

The MCAs were analyzed for total solids using Mojonnier Milk Tester (Milk Industry Foundation 1959), fat by Van Gaulik method (BIS 1979), protein by micro-Kjeldahl method (Jayaraman 1981), pH (Patel et al. 1986) and ash (BIS 1961). The salt content of cheese was determined by modified Volhard method (Kosikowski 1982). Rennet casein was analyzed for total solids, fat, protein and ash content; the procedure for TS, protein and ash was same as for cheese analogue. The fat content of rennet casein was carried out using Mojonnier fat extraction method (BIS 1965).

\section{Texture profile analysis of cheese analogues}

Compression (70\% compression) testing of tempered $\left(23 \pm 1{ }^{\circ} \mathrm{C}\right)$ cubical $\left(1 \mathrm{~cm}^{3}\right)$ cheese analogue samples was carried out using M/s. Lloyd Instrument (Model 1000, Lloyd Ltd, LRX, England; Sr. No. 160374) using 5 Kilo Newton (KN) load cell at cross-head speed of $20 \mathrm{~mm} / \mathrm{min}$. The textural characteristics of the cheese samples were directly displayed on the monitor of the computer as graph [Load (N) vs. time (s)] as well as derived values in tabular form. The gumminess and chewiness of cheese analogue samples was interpreted from their force-distance compression curve. Five cubic cheese samples were used for each treatment under study and the average of these readings was reported.

\section{Sensory evaluation of cheese analogue judged as a pizza topping}

Freshly prepared pizza base $(\sim 15 \mathrm{~cm}$ diameter, $1.5 \mathrm{~cm}$ thick) was procured from a local bakery from Anand, Gujarat. Freshly shredded cheese (70 g) was topped on each pizza base. Vegetable topping was deliberately avoided to permit flavor perception from cheese used as pizza topping. The pizza base topped with cheese were transferred to a baking oven (KENSTAR 3D-Power model OM-34ECR) maintained at $230{ }^{\circ} \mathrm{C}$ under convection mode and kept there (about $3.0 \mathrm{~min}$ ) until the cheese shreds melted completely. The segmented triangular pieces of pizza, obtained with the help of a pizza cutter, were served to each judge in hot condition (within 2 min of removing from oven) for sensory evaluation. The cheese analogue, as pizza topping, was assessed on the basis of sensory quality by a panel of ten judges (aged between 35 and 50 years) who were well aware of the desired characteristics of Pizza cheese. The judges were selected based on 'Duo-trio' and 
'Triangle' tests. Maximum score of 10.0 was used for sensory attributes like appearance (including fat leakage, browning), flavor, melting, stringiness and chewiness. The total sensory score for each cheese analogue was given out of 50.0 .

\section{Baking properties}

MCA was analyzed subjectively for shredability using a manual stainless steel shredder (pore size of opening $-3 \mathrm{~mm}$ diameter). Meltability was tested by Schrieber test (Park et al. 1984), stretchability using Fork test (USDA 1980) and fat leakage by the method of Breene et al. (1964).

\section{Microbiological analysis}

The freshly prepared MCA (RC:WPC, 90:10) was subjected to analysis for Standard Plate Count, Yeast and Mold count and Coliform count as per standard procedures (Marth and Steele 2001).

\section{Statistical analysis}

Five replicate values of each attribute were subjected to statistical analysis using Completely Randomized Design (CRD) with equal number of observations (Steel and Torrie 1980).

\section{Results and discussion}

\section{Formulation of Mozzarella cheese analogue}

Mozzarella cheese analogue (MCA) was made using varying proportions of RC and WPC (i.e. 95:5, 90:10, and $85: 15)$ in the formulation, keeping the rate of addition of blend of protein powder (i.e. 23.5\%) constant (Table 1). Rest of the ingredients (i.e. vegetable fat, cheese flavoring, acid, emulsifying salt and common salt) and their levels were kept constant. The manufacturing protocol adopted was the same as standardized by Shah et al. (2010) using vegetable fat instead of plastic cream and adopting the formulation shown in Table 1. The photographs of MCAs made using formulation containing three proportions of RC and WPC (i.e. 95:5, 90:10, and 85:15) as the protein source is shown in Fig. 1.

\section{Composition of Mozzarella cheese analogue}

Legal standards dictate the compositional attributes of cheese and cheese analogues. The composition of cheese in turn affects the end use functionality of the cheese product. The data depicted in Table 2 indicates that the only parameters that were significantly $(P<0.05)$ affected by changing the proportion of RC and WPC as protein source were fat on dry matter (FDM) and ash content of MCAs. The FDM content of MCA made using RC:WPC (90:10) was the least (i.e. 42.60\%) which differed significantly $(P<0.05)$ from the FDM of MCAs made using proportions 85:15 (i.e. 42.66\%) and 95:05 (i.e. $42.72 \%$ ). The ash content of MCAs tended to decrease as the proportion of WPC was increased in the protein powder blend. MCA made using protein powder in 95:5 had the highest ash content, which differed significantly $(P<0.05)$ from the ash content of other two analogues; the analogues made using 90:10 and 85:15 protein sources also differed significantly $(P<0.05)$ from each other. Since MCA made using RC:WPC (95:5) had slightly higher fat content and had the least moisture content, it obviously had highest FDM content (Table 2). Since the ash content of rennet casein (i.e. $8.32 \%$ ) was greater than that of WPC (i.e. $4.19 \%$ ), increasing the proportion of WPC in the protein mixture led to resultant MCAs having decreased ash content.

Based on the FSSA (2011) requirement for moisture (maximum 54.0\%) and FDM (minimum 35.0\%) content for natural Mozzarella cheese (Pizza cheese variant), all the three MCAs could satisfy such criteria, however the fat was of vegetable origin in case of cheese analogues.
Table 1 Formulation of Mozzarella cheese analogues

\begin{tabular}{llc}
\hline Source & Ingredients (w/w) & Usage level (\%) \\
\hline Fat & Specialty vegetable fat (Palm oil based) & 15.00 \\
Protein & Rennet casein $+\mathrm{WPC}^{\mathrm{a}}$ & 23.50 \\
Emulsifying salt & Trisodium citrate + Disodium hydrogen orthophosphate (3:1, w/w) & 2.50 \\
Acid & Citric acid & 0.60 \\
Cheese flavour & Mozzarella cheese bud flavour & 1.50 \\
Seasoning & Common salt & 1.10 \\
Calcium source & Calcium chloride & 0.07 \\
Moisture & Water & 55.73 \\
& Total & 100.00 \\
\hline
\end{tabular}

${ }^{a}$ Three proportions of rennet casein + WPC were tried out 

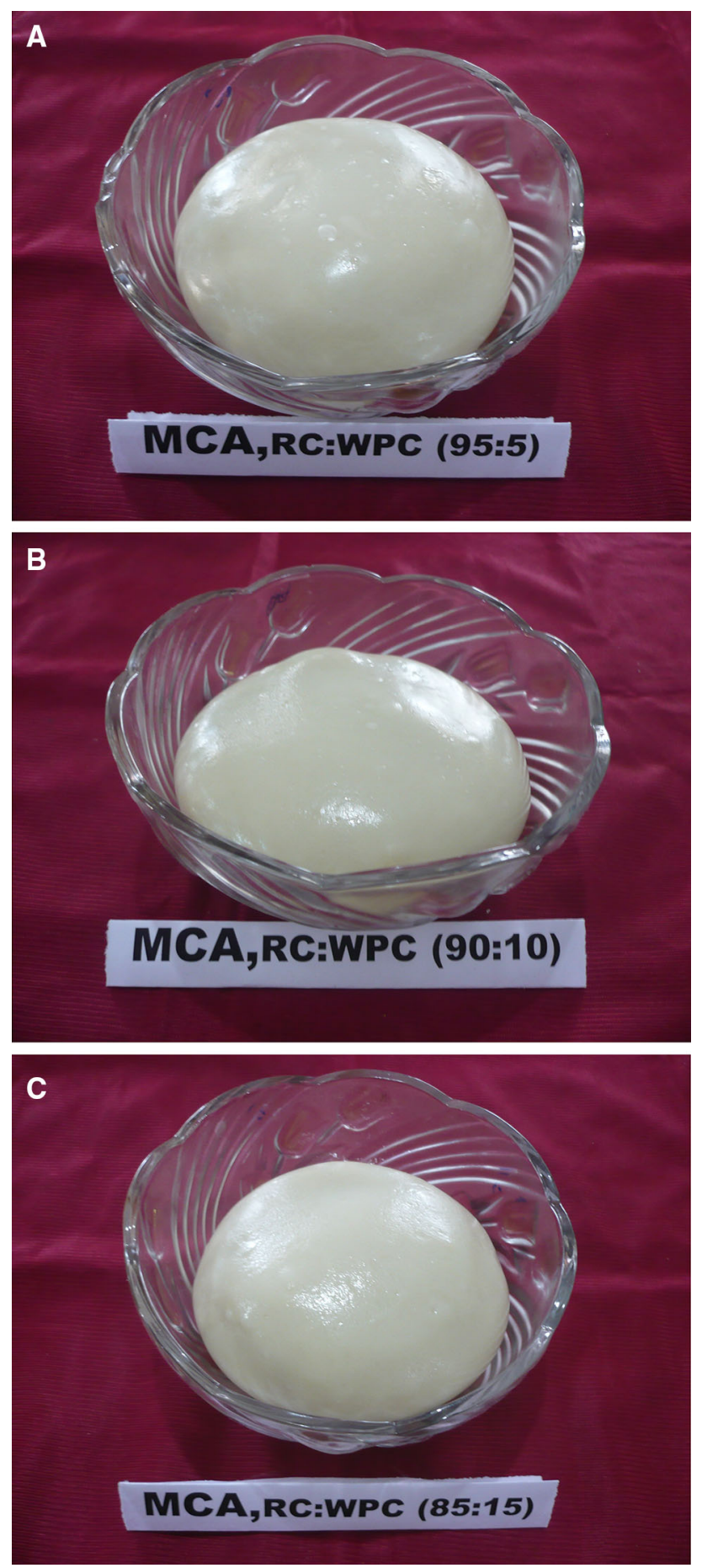

Fig. 1 Photographs of Mozzarella cheese analogues made using rennet casein and whey protein concentrate at proportions of a 95:5, b $90: 10$, and c $85: 15 \mathrm{w} / \mathrm{w}$

\section{Textural characteristics of Mozzarella cheese analogue}

The textural characteristics of MCA are important parameter that has to be controlled so that the end use functionality of cheese product remains fairly constant. Some of the textural properties of cheese product dictate the functionality (i.e. shredding, stretch, meltability) of the resultant product. The results depicted in Table 3 clearly shows that varying the proportion of the two protein sources (i.e. $\mathrm{RC}$, WPC) had a significant influence on most of the textural parameters of MCAs, exception being for springiness and adhesiveness. The hardness of MCA tended to decrease with increasing proportion of WPC used in the protein powder blend. The highest hardness of MCA made using RC:WPC (95:5) differed significantly $(P<0.05)$ from the values of other two MCAs; the analogues made using 90:10 and 85:15 proportions also differed significantly $(P<0.05)$ from each other. The cohesiveness of MCAs made using protein powders RC:WPC in 90:10 and 85:15 proportion were at par with each other; such cohesiveness values were significantly $(P<0.05)$ greater than the value associated with MCA made using RC:WPC, 95:5 proportion (Table 3).

Gumminess and chewiness is basically the product of basic textural parameters and hence were affected significantly by the change in the proportion of RC and WPC in the protein blend. The values of gumminess and chewiness of MCAs tended to decrease as the proportion of WPC increased in the protein powder blend; such effect was found to be significant $(P<0.05)$ for gumminess when all the three MCAs were compared with each other (Table 3). With respect to chewiness, MCA made using RC:WPC of 95:5 blend had the highest value which differed significantly $(P<0.05)$ from the values of other two MCAS; the other two MCAs were at par with each other with regard to chewiness. Springiness which is somewhat related to stringiness (stretch) of cheese analogue (since springiness is assessed at $23{ }^{\circ} \mathrm{C}$ temperature while stringiness is assessed at pizza baking temperature) remained unaffected by the presence of WPC at few levels in admixtures with rennet casein (Table 3).

As the proportion of whey protein in the protein mixture rose, it probably interfered with the protein matrix created predominantly by casein protein resulting in decreased cheese hardness. However, since the denatured whey proteins (due to processing treatment involved in cheese analogue manufacture) probably aided in better binding with casein, it led to cheese analogues having greater cohesiveness, when the proportion of whey protein was raised in the protein powder blend. Addition of denatured whey protein to the base mixture (i.e. $8.0 \%$ butter fat, $40.0 \%$ hard cheese, $2.0 \%$ soft curd and $3.0 \%$ emulsifier) is reported to decrease the firmness of the process cheese product (Salem et al. 1987).

\section{Baking characteristics of MCA}

Use of calcium-sequestering salts (emulsifying salts) such as trisodium citrate (TSC) is indispensable in the 
Table 2 Composition of Mozzarella cheese analogue made using varying proportion of rennet casein and whey protein concentrate

\begin{tabular}{lccc}
\hline Parameters & \multicolumn{3}{l}{ Composition of MCA made using Rennet casein:WPC (w/w) } \\
\cline { 2 - 4 } & $95: 5$ & $90: 10$ & $85: 15$ \\
\hline Moisture (\%) & $48.20 \pm 0.65^{\mathrm{a}}$ & $48.36 \pm 0.81^{\mathrm{a}}$ & $48.50 \pm 0.86^{\mathrm{a}}$ \\
MFFS (\%) & $61.90 \pm 0.61^{\mathrm{a}}$ & $62.00 \pm 0.77^{\mathrm{a}}$ & $62.15 \pm 0.84^{\mathrm{a}}$ \\
Fat (\%) & $22.13 \pm 0.28^{\mathrm{a}}$ & $22.00 \pm 0.34^{\mathrm{a}}$ & $21.97 \pm 0.33^{\mathrm{a}}$ \\
Fat on dry matter (\%) & $42.72 \pm 0.01^{\mathrm{a}}$ & $42.60 \pm 0.02^{\mathrm{b}}$ & $42.66 \pm 0.07^{\mathrm{a}}$ \\
Protein (\%) & $23.79 \pm 0.24^{\mathrm{a}}$ & $23.75 \pm 0.31^{\mathrm{a}}$ & $23.70 \pm 0.40^{\mathrm{a}}$ \\
Protein (at 48\% moisture) (\%) & $23.88 \pm 0.06^{\mathrm{a}}$ & $23.92 \pm 0.06^{\mathrm{a}}$ & $23.93 \pm 0.01^{\mathrm{a}}$ \\
Salt $(\%)$ & $1.34 \pm 0.02^{\mathrm{a}}$ & $1.33 \pm 0.02^{\mathrm{a}}$ & $1.31 \pm 0.03^{\mathrm{a}}$ \\
Ash (\%) & $5.32 \pm 0.10^{\mathrm{a}}$ & $5.10 \pm 0.15^{\mathrm{b}}$ & $4.90 \pm 0.14^{\mathrm{c}}$ \\
pH & $6.08 \pm 0.03^{\mathrm{a}}$ & $6.06 \pm 0.05^{\mathrm{a}}$ & $6.03 \pm 0.03^{\mathrm{a}}$ \\
\hline
\end{tabular}

Figures placed after \pm indicates standard deviation, Differing letters as superscript in the same row indicate significant difference at $P<0.05$

MCA Mozzarella cheese analogue, WPC whey protein concentrate

\# Moisture-in-fat-free substances

\begin{tabular}{lccr}
\hline Parameters & \multicolumn{2}{l}{ Textural properties of MCA made using RC:WPC $(w / w)$} \\
\cline { 2 - 4 } & $95: 5$ & $90: 10$ & $85: 15$ \\
\hline Hardness (N) & $22.55 \pm 0.40^{\mathrm{a}}$ & $17.75 \pm 0.12^{\mathrm{b}}$ & $16.45 \pm 0.08^{\mathrm{c}}$ \\
Cohesiveness & $0.35 \pm 0.006^{\mathrm{b}}$ & $0.37 \pm 0.003^{\mathrm{a}}$ & $0.38 \pm 0.01^{\mathrm{a}}$ \\
Springiness (mm) & $4.25 \pm 0.07^{\mathrm{a}}$ & $4.17 \pm 0.03^{\mathrm{a}}$ & $4.20 \pm 0.10^{\mathrm{a}}$ \\
Gumminess (N) & $789.25 \pm 27.85^{\mathrm{a}}$ & $663.87 \pm 8.85^{\mathrm{b}}$ & $625.38 \pm 29.68^{\mathrm{c}}$ \\
Chewiness (Nmm) & $33.54 \pm 1.77^{\mathrm{a}}$ & $27.68 \pm 0.59^{\mathrm{b}}$ & $26.29 \pm 1.89^{\mathrm{b}}$ \\
Adhesiveness (Nmm) & $0.44 \pm 0.08^{\mathrm{a}}$ & $0.46 \pm 0.01^{\mathrm{a}}$ & $0.45 \pm 0.07^{\mathrm{a}}$ \\
\hline
\end{tabular}

Figures placed after \pm indicates standard deviation, Differing letters as superscript in the same row indicate significant difference at $P<0.05$

$M C A$ Mozzarella cheese analogue, $R C$ rennet casein, $W P C$ whey protein concentrate
Table 3 Influence of varying proportions of rennet casein and whey protein concentrate on the textural characteristics of Mozzarella cheese analogue manufacture of MCA to disrupt the calcium-mediated cross-bridges between the proteins. The addition of emulsifying salts promotes casein peptization, which increases the water binding capacity of the proteins and exposes their polar hydrophilic and a polar hydrophobic segments (Chavan and Jana 2007). Hydration of the protein is also affected by the shear conditions used; high shear leading to faster and more extensive disruption of the rennet casein particles and an increased opportunity for protein-solvent interactions. Exposure of increased numbers of hydrophilic regions on protein molecules allows the rennet casein to hydrate and form a highly viscous protein-aqueous phase capable of emulsifying oil and increasing the viscosity of the protein dispersion. Hence, the state of protein (rennet casein) hydration influences the rheological parameters of the resultant product (Ennis et al. 1998; Ennis and Mulvihill 1999), which should be sufficiently firm to allow shredding and when cooked, the cheese should exhibit good meltability, stretchability and elasticity. These performance characteristics of the cheese analogues are influenced by the precise nature of protein in aqueous phase, and the nature of the emulsion formed.

The baking properties evaluated include shred quality, meltability, fat leakage and stretch; shred quality was assessed subjectively. Table 4 indicates that the objectively assessed baking qualities (i.e. melt, fat leakage) were not significantly affected by varying the proportions of RC and WPC in the MCA formulation. This implies that though some of the textural characteristics of MCA were significantly affected by incorporation of WPC at few levels in admixture with rennet casein, the baking properties of cheese analogues remained unaffected. The individual baking property of cheese analogue is discussed in detail below.

Shredding Shredability and resistance to clumping after shredding are the major determinants of overall functional characteristics of cheese (Apostolopoulos and Marshall 1994). Nowadays, Mozzarella cheese producers are also catering 'packaged shredded cheese' to confer convenience to the end users of cheese. Hence shredding property is an 
Table 4 Baking qualities of Mozzarella cheese analogue and its sensory quality as pizza topping as affected by the varying proportions of rennet casein and whey protein concentrate

\begin{tabular}{|c|c|c|c|}
\hline \multirow[t]{2}{*}{ Parameters } & \multicolumn{3}{|c|}{ Baking quality of MCA made using Rennet casein: WPC (w/w) } \\
\hline & $95: 5$ & $90: 10$ & $85: 15$ \\
\hline \multicolumn{4}{|l|}{ Baking qualities } \\
\hline Shredability & Very good & Very good & Good \\
\hline Schreiber meltability (arbitrary value) & $4.39 \pm 0.27^{\mathrm{a}}$ & $4.50 \pm 0.36^{\mathrm{a}}$ & $4.79 \pm 0.39^{\mathrm{a}}$ \\
\hline Melting time in oven at $230^{\circ} \mathrm{C}(\mathrm{s})$ & $184.00 \pm 5.87^{\mathrm{a}}$ & $185.00 \pm 13.77^{\mathrm{a}}$ & $184.00 \pm 3.39^{\mathrm{a}}$ \\
\hline Fat leakage $\left(\mathrm{cm}^{2}\right)$ & $5.70 \pm 0.49^{\mathrm{a}}$ & $5.25 \pm 0.28^{\mathrm{a}}$ & $5.20 \pm 0.56^{\mathrm{a}}$ \\
\hline Stretch test $(\mathrm{cm})$ & $17.50 \pm 0.85^{\mathrm{a}}$ & $17.20 \pm 0.57^{\mathrm{a}}$ & $17.00 \pm 0.90^{\mathrm{a}}$ \\
\hline \multicolumn{4}{|l|}{ Sensory attributes } \\
\hline Appearance (10) & $7.84 \pm 0.06^{\mathrm{a}}$ & $7.96 \pm 0.26^{\mathrm{a}}$ & $8.08 \pm 0.32^{\mathrm{a}}$ \\
\hline Flavour (10) & $7.88 \pm 0.04^{\mathrm{b}}$ & $8.38 \pm 0.22^{\mathrm{a}}$ & $8.35 \pm 0.24^{\mathrm{a}}$ \\
\hline Melting (10) & $8.28 \pm 0.32^{\mathrm{a}}$ & $8.35 \pm 0.03^{\mathrm{a}}$ & $8.35 \pm 0.16^{\mathrm{a}}$ \\
\hline Stringiness (10) & $7.94 \pm 0.38^{\mathrm{a}}$ & $8.27 \pm 0.08^{\mathrm{a}}$ & $8.28 \pm 0.20^{\mathrm{a}}$ \\
\hline Chewiness (10) & $7.55 \pm 0.06^{\mathrm{b}}$ & $8.35 \pm 0.28^{\mathrm{a}}$ & $8.20 \pm 0.11^{\mathrm{a}}$ \\
\hline Total score (10) & $39.49 \pm 0.55^{\mathrm{b}}$ & $41.31 \pm 0.70^{\mathrm{a}}$ & $41.26 \pm 0.94^{\mathrm{a}}$ \\
\hline
\end{tabular}

Figures placed after \pm indicates standard deviation, Differing letters as superscript in the same row indicate significant difference at $P<0.05$

MCA Mozzarella cheese analogue important criterion for MCA. Upon shredding, if the cheese could be shred with ease and the resultant shreds obtained were thin and long, without any tendency to mat with each other post shredding, the shredability was considered to be 'Very good'. If the cheese offered some resistance while shredding (not with ease) and the shreds obtained were short and thick, with some tendency to mat with each other post shredding, the shredability was considered to be 'Good'. As is evident from Table 4, the shredding characteristic of MCA made using RC:WPC of 95:5 and 90:10 was rated as 'Very good'; whereas MCA made using RC:WPC of 85:15 had 'Good' shred quality (Table 4). In case of 95:5 MCA, the shreds obtained were thick and somewhat long. In case of 90:10 cheese, the shreds obtained were short and had a tendency to mat with each other. In case of 85:15 cheese, the shreds were long but had greater tendency to mat with each other post shredding.

Meltability Meltability refers to the capacity of the cheese particles to coalesce to a uniform, continuous layer of melted cheese when placed in the baking oven. Once the pizza base topped with shredded cheese is put in the baking oven, it is allowed to stay in the oven till the cheese shreds melts completely to form a uniform 'circular sheet' ready to be retrieved from the oven for consumption. Though non-significant, the meltability of MCA made using RC:WPC of 85:15 was somewhat superior over that of other two MCAs. Cheese having greater meltability is preferred in baked pizza. Likewise, the time required by all the three MCAs (i.e. 95:5, 90:10, 85:15) to melt in the oven was almost the same.
Fat leakage Free oil formation is the tendency of oil (milk fat) to separate from the melted cheese and form oil pockets, upon baking. The high temperature of air in the baking oven makes the protein to decrease its state of emulsification, consequently leading to release of few droplets of free oil at the surface of melted cheese Some degree of free fat in baked melted cheese is desirable; excessive amount is derogatory to its appearance, palatability and crispness (Breene et al. 1964).Though non-significant, the fat leakage was somewhat lower for MCA made using RC:WPC of 85:15 compared to their counterparts made using $95: 5$ and $90: 10$ proportion of protein mixture (Table 4).

Stretch Stretchability is the ability of the melted cheese to form fibrous strands that elongate without breaking under tension (Jana 2001).The stretch of Mozzarella cheese should be minimum $7.5 \mathrm{~cm}$ measured from the surface of pizza (USDA 1980).Though non-significant, as the proportion of WPC increased (i.e. 95:5-85:15) in the MCA formulation, there was slight reduction in the stretch value (Table 4). The photographs of melted cheese analogues subjected to stretch test is shown in Fig. 2.

The above findings reveal that the baking properties of MCA remained unaffected by the presence of WPC in admixture with rennet casein at the three levels studied.

\section{Sensory characteristics of Mozzarella cheese analogue judged as a pizza topping}

According to one survey, Mozzarella cheese manufacturers considered shredability, meltability, stretchability, 

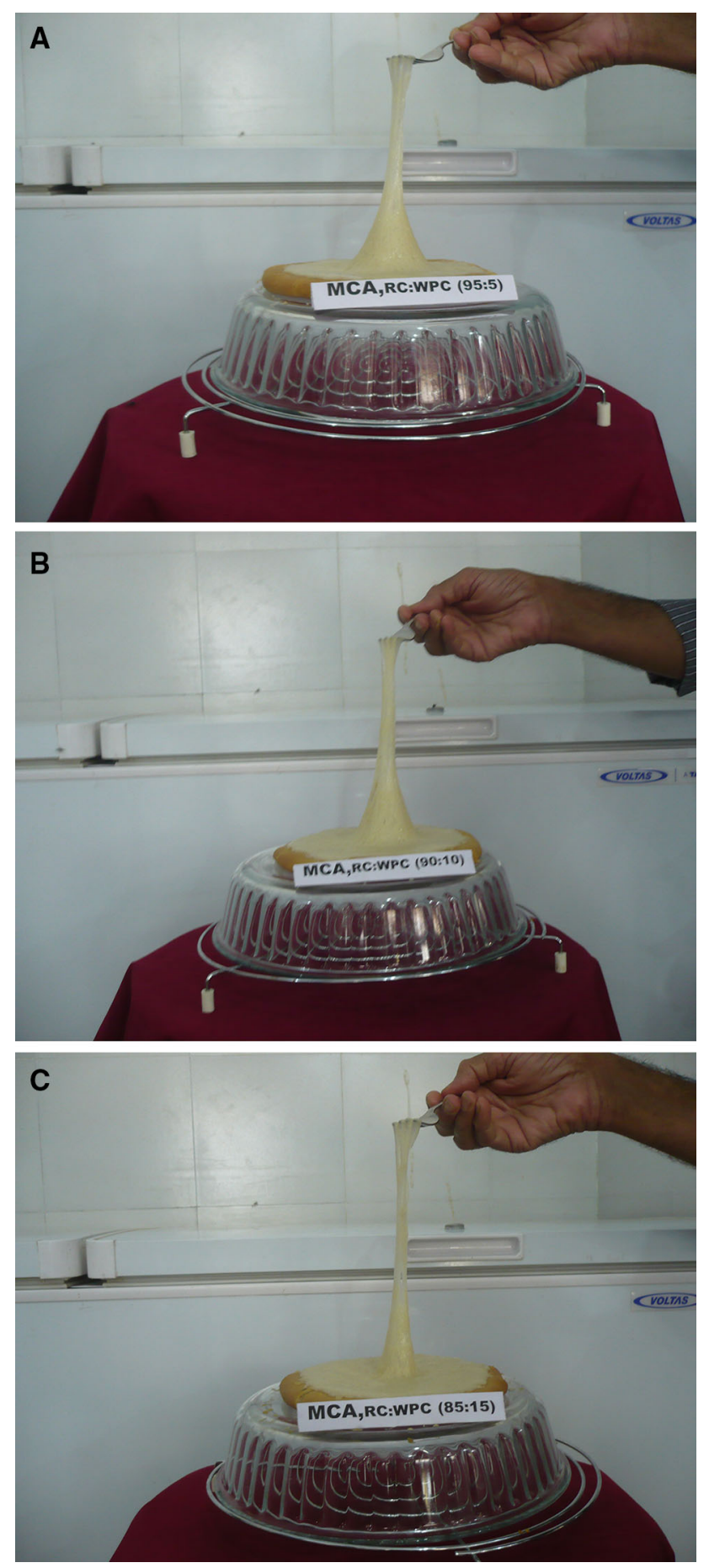

Fig. 2 Fork stretch test of Mozzarella cheese analogues made using rennet casein and whey protein concentrate $(95: 5,90: 10,85: 15 \mathrm{w} / \mathrm{w}$; a-c respectively)

elasticity and stringiness to be equally important for consumer satisfaction. On the other hand, for pizza retailers, the most important attributes were flavour, shredability and meltability (Savage and Mullan 1996).

The data furnished in Table 4 indicates that use of WPC in admixture with rennet casein as the protein source had a significant $(P<0.05)$ influence on the sensory flavor, chewiness and total sensory score of the resultant cheese analogues, when judged as pizza topping.

The detailed description of each sensory attribute of cheese is as given below.

Appearance All the MCAs appeared 'dull white' in appearance which might be due to inclusion of WPC in the protein blend. WPC was a light brown colored powder, while rennet casein was white powder. The fat leakage was moderate in case of MCAs made using protein blends 85:15 and 95:5 (RC:WPC), whereas it was least in case of MCA made using RC:WPC(90:10). Browning was not evident in any of the cheese samples, when judged as pizza topping.

Flavour The flavor score of MCAs made using RC:WPC of 90:10 and 85:15 was significantly $(P<0.05)$ superior to that made using 95:5 protein blend; the former two MCAs were at par with each other in this respect. This implied that use of relatively higher quantum of WPC in admixtures with RC in preparation of MCA led to superior flavor of cheese product. Such influence might have been owing to the subdued flavor of rennet casein in MCAs containing higher rate of addition of WPC. The subdued flavor of rennet casein might have permitted better perception of cheese flavor contributed by the cheese flavouring used in the formulation.

Melting All the three MCAs melted evenly throughout the circumference of the pizza base; all behaved identically in this respect.

Stringiness Stringiness is the property of Mozzarella cheese that is prized by the consumers during consumption of pizza topped with cheese. All the three MCAs stretched equally well during consumption of the hot pizza containing cheese as topping and hence all the cheeses got stringiness rating that was at par with each other (Table 4).

Chewiness During mastication of the cheese during consumption of pizza, moderate degree of chewiness is preferred by the consumers. Of the three MCAs, the one made using protein blend RC:WPC (95:5) had the highest chewiness (and hence scored lower); the chewiness score of such MCA was significantly $(P<0.05)$ lower than the scores allotted to other two cheese samples. The latter two MCAs had identical chewiness score (Table 4). MCA based solely on rennet casein as the protein source tended to be firmer and chewier (Hoffmann et al. 2005; Jana et al. 2015), hence use of food additives like modified starches are used to attain resultant cheese analogues having desired (moderate) chewiness during consumption of pizza topped with cheese (Mounsey and O'Riordan 2008). The presence of higher proportion of WPC in MCA made using protein blend 90:10 and 85:15 (RC:WPC) led to such product being less firm (Table 3) compared to the one containing least quantum of WPC (i.e. 95:5), culminating in moderate degree of chewiness in the former two MCAs (Table 4). 
Total sensory score The total sensory score of the MCA, judged as pizza topping, made using the protein blends was in decreasing order: 90:10 $>85: 15>95: 5$. The former two MCAs had significantly $(P<0.05)$ superior total sensory score when compared to the one made using 95:5 (RC:WPC) protein blend. The former two MCAs (i.e. made using RC:WPC of 90:10 and 85:15) judged as pizza topping, had total sensory score that was at par with each other (Table 4). The significantly lower score for flavor and chewiness associated with MCA made using RC:WPC (95:5) led to such cheese product having the least total sensory score too.

MCA made using either of 90:10 or 85:15 protein blends (RC:WPC) behaved satisfactorily as a pizza topping. However, looking to the superiority of MCA made using RC:WPC (90:10) with regard to shred quality and marginal superiority in terms of the total sensory score of cheese as pizza topping, such protein blend (i.e. RC:WPC, 90:10) is recommended when used at the rate of $23.5 \%$ by weight in the MCA formulation. Such protein powder blend yielded an analogue that had superior functional properties for use on pizza such as flavor, chewiness and fat leakage.

\section{Microbial quality of MCA}

The Standard Plate Count of MCA made utilizing rennet casein: WPC (90:10) was 15,000 per $g$ of fresh sample. Coliform as well as Yeast and Mold were not detected in $1 \mathrm{~g}$ of fresh sample of such MCA.

\section{Conclusion}

Based on the above results, use of 90:10 (RC:WPC) is recommended as the protein source to be used at the rate of $23.5 \%$ by weight in the formulation of MCA taking into consideration the sensory and objective baking qualities of cheese analogues. Incorporation of WPC in MCA helped in improving the nutritional profile (healthy product) of cheese product making, helped in better perception of cheese flavor and reduced the chewiness of product making the cheese, used as pizza topping, more palatable.

\section{References}

Almeida C, Alvares TS, Costa MP, Conte Junior CA (2016) Protein and amino acid profiles of different whey protein supplements. J Diet Suppl 13:313-323

Anon (2008) Whey protein. Altern Med Rev 13(4):341-347. Cited from http://chocolift.com.br/wp-content/uploads/2013/07/11.Whey_Protein_Monografia.pdf. Accessed on 15 Jan 2014
Apostolopoulos C, Marshall RJ (1994) A quantitative method for the determination of shredability of cheese. J Food Qual 17:115-128

BIS (1961) Methods of test for dairy industry. Rapid examination of milk. Bureau of Indian Standards (BIS), IS-1479 (part-I), Manak Bhavan, New Delhi, India, pp 1-57

BIS (1965) Specification for edible casein. IS-1167, Bureau of Indian Standards (BIS), Manak Bhavan, New Delhi, India

BIS (1979) Methods for determination of fat in cheese by Van Gaulik method. BIS: 9070, Indian Standards Institution, New Delhi, p 4

Breene WM, Price WV, Ernstrom CA (1964) Manufacture of Pizza cheese without starter. J Dairy Sci 47:1173-1180

Chavan R, Jana A (2007) Cheese substitutes: an alternative to natural cheese-a review. Int J Food Sci Technol Nutr 2:25-39

Dairy Facts (2006) International Dairy Foods Association, Washington, DC

Dees AL (2002) Effects of various ingredients on a model process cheese system. M.Sc. thesis submitted to the Graduate Faculty of North Carolina State University, Raleigh. Cited from www.repository.lib.ncsu.edu/ir/bitstream/1840.16/338/1/ etd.pdf

Ennis MP, Mulvihill DM (1999) Compositional characteristics of rennet caseins and hydration characteristics of the caseins in a model system as indicators of performance in Mozzarella cheese analogue manufacture. Food Hydrocoll 13:325-337

Ennis MP, O‘Sullivan MM, Mulvihill DM (1998) The hydration behaviour of rennet casein in calcium chelating salt solution as determined using a rheological approach. Food Hydrocoll 12:451-457

Forsum E (1973) Nutritional evaluation of whey protein concentrates and their fractions. J Dairy Sci 27:665-670

Fox PF, Guinee TP, Cogan TM, Mc Sweeney PLH (2017) Fundamentals of cheese science, 2nd edn. Springer, New York

FSSA (2011) Food safety and standards act (FSSA). Cited from http:// fssai.gov.in. Accessed on 4 Jan 2016

Hoffmann W, Hinrichs M, Johannsen N, Scheurer G, MaurerRothmann A (2005) Use of different acid caseins in analogue low-moisture Mozzarella. Milchwissenschaft 60:395-398. INIST-CNRS, cote INIST: 4873, 35400013173290.0130

Jana A (2001) Mozzarella cheese and pizza-the compatible partners. Beverage Food World 28:14-19

Jana AH, Rahul Shah, Aparnathi KD, Dhanraj Padhiyar (2015) Influence of rennet casein levels on the chemical, baking and sensory quality of Mozzarella cheese analogue. J Dairy Vety Anim Res 2:39-45. doi:10.15406/jdvar.2015.02.00039

Jayaprakasha HM, Brueckner H (1999) Whey protein concentrate: a potential functional ingredient for food industry. J Food Sci Technol 36:189-204

Jayaraman J (1981) Laboratory manual in biochemistry. Wiley Eastern Ltd, New Delhi, p 75

Kaminarides S, Stachtiaris S (2000) Production of processed cheese using Kasseri cheese and processed cheese analogues incorporating whey protein concentrate and soybean oil. Int J Dairy Technol 53:69-74. doi:10.1111/j.1471-0307.2000.tb02661.x

Kosikowski FV (1982) Cheese and fermented milk foods, 3rd edn. Edwards Brothers Inc, Am Arbor, Michigan, USA, pp $153-167,178$

Marth EH, Steele J (2001) Applied DairyMicrobiology, Marth EH, Steele J (Eds), 2nd Edn. CRC Press, New York

Milk Industry Foundation (1959) Laboratory manual. Methods of analysis of milk and its products, 3rd edn, Washington, USA, p 283

Mounsey JS, O'Riordan ED (2008) Modification of imitation cheese structure and rheology using pre-gelatinized starches. Europ Food Res Technol 226:1039-1046. doi:10.1007/s00217-0070629-5 
Murphy KJ (1999) Properties of imitation cheese containing noncasein proteins. M.Agr.Sci. Thesis, University College Dublin, National University of Ireland, Dublin

O'Malley AM, Mulvihill DM, Singh T (2000) Proteolysis in rennet casein-based cheese analogues. Int Dairy J 10:743-753. doi:10. 1016/S0958-6946(00)00107-2

O'Riordan ED, Duggan E, O'Sullivan M, Noronha N (2011) Production of analogue cheeses. In: Tamime AY (ed) Process cheese and analogues, 1st edn. Wiley, West Sussex, pp 219-239

Park J, Rosenau JR, Peleg M (1984) Comparison of four procedures of cheese meltability evaluation. J Food Sci 49:1158-1170

Patel GC, Vyas SH, Upadhyay KG (1986) Evaluation of Mozzarella cheese made from buffalo milk using direct acidification technique. Indian J Dairy Sci 39:394-403

Salem SA, Salem AE, Gooda E (1987) Improvement of chemical, rheological and organoleptic properties for local-low fat processed cheese. Egyp J Dairy Sci 15:263-270

Savage AA, Mullan WMA (1996) Quality perceptions and expectations of Mozzarella cheese producers and pizza manufacturers. Milchwissenschaft 51:677-679
Shah R, Jana AH, Aparnathi KD, Prajapati PS (2010) Process standardization for rennet casein based Mozzarella cheese analogue. J Food Sci Technol 47:574-578. doi:10.1007/ s13197-010-0104-3

Shimp LA (1985) Process cheese principles. Food Technol 39:63-69

Sołowiej B (2007) Effect of $\mathrm{pH}$ on rheological properties and meltability of processed cheese analogues with whey products. Polish J Food Nutr Sci 57:125-128

Solowiej B, Mleko S, Gustaw W, Udeh KO (2010) Effect of whey protein concentrates on texture, meltability and microstructure of acid casein processed cheese analogues. Milchwissenschaft 65:169-172

Steel RGD, Torrie JH (1980) Principles and procedure of statistics-a biometrical approach, 2nd edn. Mc Graw Hill Kogakusha Ltd., Tokyo, pp 137-167

USDA (1980) Specification for Mozzarella cheese. Agricultural marketing service, United States Department of Agriculture (USDA), Washington, DC

www.pmfood.dk/upl/WCMINFORMATION.pdf 